Article

\title{
Sustainability, Entrepreneurship, and Disability: A New Challenge for Universities
}

\author{
Rosa M. Muñoz ${ }^{1}{ }^{10}$, Yolanda Salinero ${ }^{2, *}$ and M. Valle Fernández ${ }^{1}$ \\ 1 Business Administration Department, Faculty of Law and Social Science, Castilla-La Mancha University, \\ 13071 Ciudad Real, Spain; rosamaria.munoz@uclm.es (R.M.M.); mariavalle.fdez@uclm.es (M.V.F.) \\ 2 Business Administration Department, Faculty of Legal and Social Science, Castilla-La Mancha University, \\ 47051 Toledo, Spain \\ * Correspondence: Yolanda.salinero@uclm.es
}

Received: 31 January 2020; Accepted: 19 March 2020; Published: 23 March 2020

\begin{abstract}
There is a considerable amount of research concerning the issue of entrepreneurial intentions, which has attained mixed findings. Integrating sustainability, in the sense of considering disabled people, into the current entrepreneurial intention research makes it possible to fill an important research gap. The main objective of this paper is to clarify the contribution that education, students' traits, and contextual factors make to an individual's entrepreneurial intent when disabled students are incorporated into the analysis as an innovative field of study. The aim of this research is to analyze the entrepreneurial intentions of disabled people who are studying in higher education and compare them with non-disabled students while considering the main factors described in previous studies. In order to achieve this objective, we have carried out a logistic regression with a sample of Spanish students. The main findings are: Education does not influence students' entrepreneurial intentions, which are affected by only some of the students' traits and background conditions. Regarding the disabled students' entrepreneurial intentions, we have found no significant differences compared with those of students who are not disabled. Initiatives such as those of the University of Castilla-La Mancha (UCLM) described in the paper should, therefore, be encouraged, keeping in mind that disabled students do not always show a lack of confidence in themselves as some studies have claimed.
\end{abstract}

Keywords: entrepreneurship; education; disability; sustainability

\section{Introduction}

After the recent global crisis, European institutions developed various measures in an attempt to improve employment and achieve economic growth. One of those measures was the Entrepreneurship 2020 Action Plan, whose main objective is to extend a culture of entrepreneurship throughout the European Union. The European Commission is focused particularly on the weaker groups from the point of view of their economic circumstances: seniors, family businesses, migrants, women, and liberal professions [1]. However, one group does not appear on this list; that of disabled people. We consider that there is a gap as regards the potential role these individuals could play in entrepreneurial activities, and in this paper we, therefore, show an innovative course dealing with entrepreneurship for disabled students developed by a Spanish University.

The concept of entrepreneurship includes various phenomena, such as the opening of a new company, the expanding of businesses, innovation, the personal traits of leaders, or a social process. This last phenomenon is a movement regarding social concerns that allows entrepreneurs to change existing production and consumption trends [2]. This aspect of entrepreneurship is, in many respects, related to sustainability. Sustainability and entrepreneurship should not be considered mutually exclusive. The sustainability-related entrepreneurship approach is increasingly important as it is 
considered to be a process by which to not only produce profits, but also solve environmental and social problems [3]. In this respect, entrepreneurship should contribute to the realization of sustainable innovations that will provide benefits for the majority of society. This process can, therefore, satisfy the demands of a larger group of stakeholders. As we know, stakeholders are individuals, institutions, or groups that influence or are influenced by a company's actions in different ways. Stakeholders such as NGOs (Non-Governmental Organizations) or consumer associations usually demand environmental or social improvements [4]. In our research, disabled people have become one of these stakeholders, and their needs are the ultimate sources of entrepreneurial opportunities.

A considerable amount of research has been carried out as regards entrepreneurial intentions, although the findings have been mixed. The integration of sustainability, in respect of including disabled people in the current entrepreneurial intentions field of study, will allow us to fill an important research gap.

The principal objective of the present paper is, consequently, to clarify the contribution made by education, students' traits, and contextual factors to an individual's entrepreneurial intent, but by incorporating disabled students into the analysis in order to provide a new field of study. The aim of this research is to analyze the entrepreneurial intentions of disabled people who are studying in higher education and compare them with non-disabled students while considering the main factors described in previous studies. We have carried out a logistic regression with a sample of Spanish students. The main conclusions reached are: Education does not influence students' entrepreneurial intentions, and these intentions are influenced by only some of the students' traits and background conditions. No significant differences were found when comparing disabled students' entrepreneurial intentions with those of non-disabled students.

The rest of the paper is structured as follows. We first section presents a literature review in which we collect the main ideas and previous research concerning disability, entrepreneurship, education, and sustainability. We then go on to explain the methodology employed to carry out the research and show the main results. In the last section, we show our conclusions and discuss the limitations and our future research.

\section{Literature Review}

\subsection{Determinants of Entrepreneurial Intentions}

An entrepreneur is an economic agent who starts, organizes, manages, and controls the activities required to develop new projects. This person may discover a gap within the market and try to fill it $[5,6]$.

Several authors claim that personal inputs, such as individual predispositions and differences, and background conditions, such as geographic and environmental variables, determine people's expectations and beliefs as regards self-efficacy, which in turn lead to the formation of entrepreneurial intentions $[7,8]$.

With regard to entrepreneurs' dimensions, those most cited by researchers include the perception of obstacles, risk tolerance, locus of control, educational level, business experience, gender, place of residence, and an existing family business [8-10].

Risk tolerance is the "tendency of a decision maker either to take or to avoid risks" [11], and is considered a variable that is positively related to entrepreneurial intentions [12].

Locus of control is the extent to which people attribute the control over situations to themselves (internal locus of control) or to external factors (external locus of control). When entrepreneurs wish to control circumstances themselves, internal locus of control is present in entrepreneurship [13].

The individual's experience is one of the factors that authors have most frequently found to be significant as regards distinguishing between successful and unsuccessful entrepreneurs. Moreover, if the first venture has something to do with starting a business activity during the individual's youth, this makes this person more likely to begin another entrepreneurial activity later [14]. 
Entrepreneurial family background refers to the influence that self-employed parents may have on their children's career choices. They are a role model or share similar preferences for venture business [10]. The family evolution plays an important role in students' career preferences and, subsequently, in their entrepreneurial intention [15]. Previous studies have shown that an important proportion of students from families with self-employed parents also choose to become self-employed [16].

\subsection{Sustainability and Entrepreneurship}

Since the emergence of the concept of sustainable development, social, economic, and environmental dimensions of sustainability have been considered [17-19], all of them with the main objective of fulfilling the necessities of people living today, but within the carrying capacity of the earth so that future generations are not damaged. The so-called social and solidarity economy addresses current challenges such as social exclusion, inequality, climate change, or unemployment. Its priorities are to create a sustainable society where socially weaker groups also have opportunities [20,21].

Entrepreneurship and sustainability are currently viewed as binary concepts because many researchers consider that entrepreneurial action is desirable in order to discover opportunities, innovate, and produce profits, while social and environmental challenges are included in the process [22,23].

The relationship between sustainability and entrepreneurship has been addressed from several points of view, such as those of ecopreneurship, institutional entrepreneurship, sustainable entrepreneurship, and social entrepreneurship [24,25]. In this paper, we have adopted the last approach, incorporating disabled people into the analysis. This type of entrepreneurship is focused on "improving social wealth through the creation of social capital, social change, or focus on social needs" [26]. We consider that this is an appropriate point of view because social entrepreneurship is the desire to attain societal objectives by means of business and entrepreneurship approaches [4]. The factor that distinguishes social entrepreneurship from commercial entrepreneurship is that it attempts to solve social problems rather than covering market needs [27]. Inclusive entrepreneurship leads to social inclusion, giving target groups such as women, seniors, youth, immigrants, minorities, and disabled people an equal opportunity to launch a business [28].

The establishment of new ventures by disabled people is an important aspect of sustainable employment strategies. We should not, however, confuse entrepreneurship with self-employment. The former concerns providing something innovative to the market, while the latter concerns performing work for personal profit. Simply encouraging self-employment will not, therefore, have a significant effect on employment. Policies should focus on disabled people who carry out entrepreneurial activities that may lead to the hiring of others.

\subsection{Entrepreneurship, Education and Disability}

Disability is growing in all countries. There are more than 1000 million people with disabilities throughout the world, that is, about $15 \%$ of the world's population, or one in seven people. The World Health Organization defines disability as a general term that covers activity limitations, impairments, and participation restrictions [29]. It is an individual limitation that can be different in type, duration, and severity. This signifies that, as disabilities vary, so do entrepreneurial motivations [30].

Several studies have highlighted the important role that entrepreneurship education, business incubators, and university initiatives play in students' intentions to start a new venture [31]. In addition to entrepreneur's traits, university activities that lead students to launch a new business have also been considered in earlier research [32]. However, little has been written about the factors that influence the entrepreneurial intentions of disabled starters entering the labor market. Some of these factors are not changeable, such as gender or age, but other factors can be improved. Education, an important promoting activity for employment, is a clear example of this [33].

Disabled people's entrepreneurial challenges can be financial, personal, or societal. They often have difficulties in financing their new ventures as they do not manage their own funds and banks are reticent to provide them with loans [5]. At a personal level, these potential entrepreneurs often 
lack training and business, legal, and financial knowledge. They also show a lack of confidence in themselves [28]. From the societal point of view, discrimination by stakeholders is a reality that is related to the way in which people with disabilities are viewed by society [34]. Disabled people are underrepresented in the workforce, since employers underestimate their capabilities and are particularly wary of hiring employees with intellectual or psychiatric disabilities [35]. However, several studies conclude that individuals with disabilities succeed to roughly the same extent as non-disabled entrepreneurs [36], and are even significantly more likely to confront greater challenges when compared to other potential entrepreneurs [37].

The main ideas presented above in relation to entrepreneurs' characteristics, education, and disability have led to the following hypotheses:

Hypothesis (H1). Students' traits and background conditions influence their entrepreneurial intentions.

We analyze those variables included in previous studies that were considered as most influential in entrepreneurial behavior: the perception of obstacles, risk tolerance, locus of control, educational level, business experience, gender, place of residence, and an existing family business.

Hypothesis (H2). Education influences students' entrepreneurial intentions.

The knowledge acquired about how to plan, finance, manage, and start a business works as an incentive for entrepreneurship.

Hypothesis (H3). Disabled students and non-disabled students do not have different entrepreneurial intentions.

Regardless of the final result, in a first step, disabled students show entrepreneurial intentions at a similar level to students without disabilities.

\section{Methodology}

The Department of Business Administration at the University of Castilla-La Mancha (UCLM) offers an entrepreneurship education course, entitled "Entrepreneurship and disability," for disabled students. This course is equivalent to nine credits in the European Credit Transfer and Accumulation System. The objectives of this course are to provide students with the opportunity to acquire abilities regarding entrepreneurship and to teach them the basic capabilities required to carry out and develop a whole business plan.

The 2018/2019 course was the third edition, with fifteen students in each class. This has resulted in the setting up of one company, while another is starting the necessary procedures to be created. The former is a cooperative that produces ecologic plant substratum from coffee dregs, while the latter is also a cooperative whose activity consists of assembling guitars. This is the first time that a course with these characteristics has been offered at a Spanish University, signifying that there are no similar publications of this nature. This paper is, therefore, a contribution to the field owing to its originality [38].

The students were surveyed using a written standardized questionnaire. The participants were the disabled students on the entrepreneurship course and students on different degrees at the UCLM during their classes. The second hypothesis was tested by collecting data from the first year and last year of each degree during the period from September 2018 to November 2018. We received 234 responses ( $92 \%$ of the students).

A lot of works have researched the variables that "drive" potential entrepreneurs through the process of starting a business. However, a gap exists in relation to the understanding of the motives that lead disabled people to start a business. We have adapted a model proposed in previous research [39] in an attempt to develop it in the context of a sample that includes disabled students. We have used a logistic regression in which the dichotomous dependent variable was created by means of the following 
question: "Have you started a business recently or are you taking steps to start one?" $(1=$ yes, $0=$ no). We have included as independent variables [39]:

- Four perceptions of obstacles. We asked the students whether they consider it difficult to start a business owing to a possible lack of financial support, the complexity of administrative procedures, difficulty in obtaining information, and an unfavorable economic climate. The individuals had to respond: strongly agree, agree, disagree, or strongly disagree. We constructed a dummy variable with a value of 1 in the case of strongly agree or agree.

- A measure of risk tolerance. The students had to evaluate the sentence "It is not advisable to start a business if there is risk of failure". A variable was constructed with the value of 1 in the case of disagree or strongly disagree.

- Locus of control. Internal locus of control is related to the feeling that everything in life depends on one's own efforts and actions, while external locus of control is related to the feeling that external conditions determine the results. In this case, the students had to respond to the question "What most influences a company's success?" by choosing from among the following five options: director's personality, general management of the firm (if they chose these, the dummy internal locus of control variable $=1$ ), overall economy, political context, or external entities (if they chose these, the dummy internal locus of control variable $=0$ because these answers are linked to the external locus of control).

We have also included other external variables, such as educational level, business experience, gender, location or place of residence, and whether the students' parents are/were self-employed because these are present in the literature concerning entrepreneurship.

Some previous studies confirm that entrepreneurship education has a positive influence on the perceived attractiveness of new business initiation. They have, however, rarely involved control groups or employed pre-testing and post-testing controls. Most studies focus on individuals with an existing predisposition toward entrepreneurship, which biases the conclusions in favor of educational activities [40]. We have, consequently, included "before-after" education by using a dummy variable that we have denominated as educational level ( $0=$ before education, $1=$ after education).

We have additionally employed a dummy variable for business experience $(0=$ no, $1=$ yes $)$ and for gender $(1=$ male, $0=$ female $)$.

Location has two possibilities: $1=$ urban area, and $0=$ rural area.

The question regarding whether the students' father, their mother, or both are/were self-employed was used to include the family context (and was denominated as entrepreneurial parents). This variable was recoded to a dummy variable $(0=$ no entrepreneurial parents, $1=$ entrepreneurial parents).

The characteristic disability is also another dummy variable $(0=$ not disabled, $1=$ disabled $)$. The aforementioned factors were the independent variables, while the response to the question concerning the possible attempt to start a business was the dependent variable.

Logistic regression is an extension of regression, but with an outcome variable that is a categorical variable and predictor variables that are continuous or categorical. This means that, given certain other information, it is possible to predict to which of two categories a company is likely to belong.

Logistic regression analysis is well suited when the dependent variable is non-metric and consists of just two groups. Compared to discriminant analysis, choosing logistic regression is justified by the fact that the multivariate normality assumptions do not need to be met. Logistic regression is much more robust when these assumptions are not met. But even if they are met, many researchers prefer this methodology to discriminant analysis because the interpretation of the results is similar to that of regression analysis results [41].

We have, therefore, used a Binomial Logit Model in order to find out which variables influence somebody when deciding whether to start a business. In simple linear regression, the outcome variable, $Y$, is obtained from the equation of a straight line. In logistic regression, rather than predicting the 
value of a variable, $\mathrm{Y}$, from several explanatory variables, we predict the probability of $\mathrm{Y}$ occurring by using given values of several explicative variables.

As with linear regression, it is necessary to decide how we enter explicative variables in the model. Stepwise methods are not generally recommended because they take important decisions away from the researcher and base them on mathematical criteria rather than sound theoretical logic. They are only really appropriate when one is proposing a hypothesis from scratch and have no empirical evidence or sensible theories about which explanatory factors are most important. We usually have some idea about which are determinant and their relative importance. We have, therefore, chosen the entry method for the logistic regression analysis.

\section{Results}

The categorical variable codings are showed in Table 1.

Table 1. Categorical variable codings.

\begin{tabular}{cccc}
\hline Variables & Codings & Frequency & Parameter Coding \\
\hline Educational level & Before education & 97 & 1.000 \\
Gender & After education & 137 & 0.000 \\
Location & Male & 136 & 1.000 \\
& Female & 98 & 0.000 \\
Business experience & Urban area & 102 & 1.000 \\
& Rural area & 132 & 0.000 \\
Entrepreneurial parents & No & 146 & 0.000 \\
& Yes & 88 & 1.000 \\
Locus of control & No & 146 & 0.000 \\
& Yes & 88 & 1.000 \\
Lack of financial support & Internal locus of control & 166 & 1.000 \\
& External locus of control & 68 & 0.000 \\
Risk tolerance & Strongly agree & 149 & 1.000 \\
& Strongly disagree & 85 & 0.000 \\
Unfavorable economic climate & Strongly agree & 111 & 0.000 \\
& Strongly disagree & 123 & 1.000 \\
Difficulty in obtaining information & Strongly agree & 147 & 0.000 \\
& Strongly disagree & 87 & 1.000 \\
Complexity of administrative procedures & Strongly agree & 53 & 1.000 \\
& Strongly disagree & 181 & 0.000 \\
Disability & Strongly agree & 111 & 1.000 \\
& Strongly disagree & 123 & 0.000 \\
& Not disabled & 202 & 0.000 \\
& Disabled & 32 & 1.000 \\
\hline
\end{tabular}

Source: author's calculation.

The results of the model parameter estimation are shown in Table 2 (the corresponding hypothesis appears next to each variable).

The fourth column in Table 2 shows which parameters are significant according to the test. Thus, for example, the parameter linked to the entrepreneurial parents variable is significant, with a confidence margin of $99 \%$. The variables unfavorable economic climate, location, and business experience have an associated coefficient that is significant for a confidence level of $90 \%$.

The present findings partially support the first hypothesis regarding the influence of students' traits and background conditions on their entrepreneurial intentions because only four dimensions are significant. The second hypothesis is not corroborated, that is, in this case, education does not influence entrepreneurial intentions. However, a clear difference is not found in the entrepreneurial intentions of those with and without disabilities, which is consistent with the third hypothesis. 
Table 2. Binomial logit model.

\begin{tabular}{cccccc}
\hline Variables & B & S.E. & Wald & Sig. & Exp(B) \\
\hline Disability (H3) & 0.549 & 0.468 & 1.374 & 0.241 & 1.732 \\
Gender (H1) & 0.420 & 0.292 & 2.073 & 0.150 & 1.523 \\
Location (H1) & 0.519 & 0.290 & 3.190 & 0.074 & 1.680 \\
Business experience (H1) & 0.497 & 0.303 & 2.693 & 0.098 & 1.644 \\
Entrepreneurial parents (H1) & 0.925 & 0.304 & 9.248 & 0.002 & 2.521 \\
Locus of control (H1) & 0.127 & 0.347 & 0.134 & 0.714 & 1.136 \\
Lack of financial support (H1) & -0.137 & 0.317 & 0.188 & 0.665 & 0.872 \\
Complexity of administrative procedures (H1) & 0.003 & 0.314. & 0.000 & 0.992 & 1.003 \\
Difficulty in obtaining information (H1) & -0.219 & 0.399 & 0.300 & 0.584 & 0.804 \\
Unfavorable economic climate (H1) & 0.518 & 0.315 & 2.703 & 0.096 & 1.678 \\
Risk tolerance (H1) & 0.265 & 0.295 & 0.806 & 0.369 & 1.303 \\
Educational level (H2) & -1.07 & 0.309 & 0.120 & 0.729 & 0.898 \\
Constant & -1.531 & 0.504 & 9.225 & 0.002 & 0.216 \\
\hline
\end{tabular}

Source: Author's calculation.

With regard to the goodness of the adjustment, we have chosen three measures: the Cox and Snell $\mathrm{R}^{2}$, the $\mathrm{R}^{2}$-Nag (the percentage of variation explained by the model's independent variables is between $11.2 \%$ and $15 \%$ ), and the Hosmer-Lemeshow statistic (in our case, this value is 0.297 for a Chi-square of 9.570 with 8 degrees of freedom, signifying that an acceptable adjustment exists because a non-significant parameter is desirable when using this test) (see Table 3).

Table 3. Goodness of the adjustment.

\begin{tabular}{cccccc}
\hline \multicolumn{2}{c}{ Hosmer-Lemeshow statistic } & \multirow{2}{*}{ 2LogLikelihood } & Cox and Snell $\mathbf{R}^{2}$ & \multirow{2}{*}{$\mathbf{R}^{\mathbf{2}}$-Nag } \\
Chi-square & df & Sig. & & & \\
\hline 9.570 & 8 & 0.297 & $294.556^{\text {a }}$ & 0.112 & 0.150 \\
\hline
\end{tabular}

Source: Author's calculation. a: The estimate ended in iteration number 4 because the parameter estimates had changed by less than 0.001 .

\section{Discussion and Conclusions}

This research helps to better understand the factors that influence entrepreneurial intentions, in addition to focusing on the gap in existing theory, policy, and practice in relation to the pressing sustainable-related issue of disability employment.

The perception of lack of financial support does not influence the probability of starting a business. The same conclusion is obtained for the lack of sufficient information. Moreover, the complex administrative procedures do not play a role in beginning an entrepreneurial activity. Only the fact of perceiving an unfavorable economic climate has a positive impact on the probability of developing a new enterprise. The difficulties involved in getting a job may lead the students to consider the possibility of starting a new venture. The risk tolerance does not have any influence on the students' entrepreneurial intentions. The variable locus of control does not appear to be relevant. Whether or not an individual believes that he/she can change events through his/her abilities does not have a significant influence on his/her entrepreneurial activity, and the same can be said for the acknowledgment that external factors affect events. The variable educational level does not appear to be relevant, that is, we were unable to find any influence of education on the perceived attractiveness of starting a new business. This is also true of the variable gender because the result does not support the general perception that men have a greater entrepreneurial intention than women [42]. Business experience significantly increases the probability of engaging in entrepreneurial activities, a conclusion obtained in many other studies. Location has a positive impact, that is, an urban environment favors entrepreneurial attitudes. An urban location provides more opportunities in every aspect related to new ventures: technical, financial, commercial, and so on. Having entrepreneurial parents significantly increases the probability 
of considering starting a business. The students have seen that a successful venture is a way of life that provides a lot of satisfactions, such as achievement, control, power of decision, growth potential, etc.

This study has shown that only some dimensions have an influence on the students' entrepreneurial intentions (H1): perception of unfavorable economic climate, entrepreneurial parents, location, and business experience. With regard to locus of control, the students in this case show a lack of belief in their own abilities to successfully engage in the creation of a new business. This conclusion is similar to those obtained in other studies developed in Bangladesh, Portugal, and Malaysia $[31,43,44]$.

The variable educational level was unable to demonstrate a significant relationship with entrepreneurial intentions (H2), which is a similar result to that obtained by some other authors [31,40]. Our recommendation is, therefore, that universities should increase their efforts regarding entrepreneurship education in order to make it more effective. They should strengthen different options, such as business incubators, technology transfer offices, or reward systems in order to influence students' intentions.

With regard to the variable disability, the fact that a respondent is disabled does not affect the probability of having entrepreneurship intentions. This is an important conclusion in the sense that disabled people can be considered on the same level as "capable" people in relation to this issue (H3). Innovations such as the "Entrepreneurship and disability" course at the UCLM should be replicated in most Universities.

The following table (Table 4), which is a summary of Table 2, shows the main results of the research:

Table 4. Model's Variables.

\begin{tabular}{cccc}
\hline Variable & $\begin{array}{c}\text { Sign of } \\
\text { Parameter B }\end{array}$ & $\begin{array}{c}\text { Significance } \\
\text { (Wald) }\end{array}$ & Conclusions \\
\hline $\begin{array}{c}\text { Unfavorable } \\
\text { economic climate }\end{array}$ & + & 0.096 & $\begin{array}{c}\text { The unfavorable economic climate has a positive impact } \\
\text { on the probability of developing a new enterprise }\end{array}$ \\
\hline $\begin{array}{c}\text { Entrepreneurial } \\
\text { parents }\end{array}$ & + & 0.002 & $\begin{array}{c}\text { Having entrepreneurial parents has a positive influence on } \\
\text { the students' entrepreneurial intentions }\end{array}$ \\
\hline Location & + & 0.074 & $\begin{array}{c}\text { Urban location has a positive effect on the students' } \\
\text { entrepreneurial intentions }\end{array}$ \\
\hline $\begin{array}{c}\text { Business } \\
\text { experience }\end{array}$ & + & 0.098 & $\begin{array}{c}\text { Business experience has a positive influence on the } \\
\text { students' entrepreneurial intentions }\end{array}$ \\
\hline Educational level & - & 0.729 & $\begin{array}{c}\text { Educational level does not appear to have a significant } \\
\text { relationship with entrepreneurial intentions. }\end{array}$ \\
\hline Disability & + & 0.241 & $\begin{array}{c}\text { Being disabled does not affect the probability of showing } \\
\text { entrepreneurship intentions. }\end{array}$ \\
\hline
\end{tabular}

Source: Author's calculation.

The results of this research will allow us to develop an intervention approach focused on supporting and promoting entrepreneurship among people who are interested in beginning a new venture. Moreover, the addition of individuals with disabilities to the model may allow us to attain a sustainability-related initiative in order to link demand from small companies with the underutilized labor supply of these types of employees.

In terms of policy implications, disabled people's low employment rates have negative consequences, such as economic implications by having underutilized productive resources and high costs through more impact on social security systems. Therefore, public policies should seek solutions for the unemployment and low activity rates among disabled people [45]. We consider that changes should continue with these types of initiatives, that is, the creation of educational programs that will provide entrepreneurship candidates with training that will lead to a business plan. Initiatives such as educational programs at different educational levels, business mentoring, technical assistance, business incubators, or start-up company grants could increase the presence of disabled people in the workforce. Furthermore, the findings of many studies evidence the influence of university 
collaborations for academic performance [46]. Knowledge exchange among universities is crucial to develop and share these types of initiatives. While policies are in place to amend some of the inequalities, it is clear that the implementation of new actions is a challenge. In this sense, this research contributes to the planning of policies on education for people with disabilities, as it shows factors that can boost their entrepreneurial inclinations.

This research provides useful conclusions in the field of entrepreneurship and its link to sustainability but has some limitations. The survey tool may incorporate a common method bias, although self-report measures are frequently used in entrepreneurial intention research. The conclusion in relation to disabled students should be viewed carefully because it has been obtained from a small sample. Moreover, the data was obtained from only one region in Spain. In future research, it would be useful to extend the sample and include more regions and countries, which would allow comparative studies. We also consider it advisable to carry out a longitudinal study in order to check whether entrepreneurial intentions eventually lead to actual entrepreneurial behavior.

Author Contributions: Conceptualization, R.M.M. and Y.S.; methodology, M.V.F.; validation, Y.S. and M.V.F.; formal analysis, R.M.M. and M.V.F.; investigation, R.M.M., Y.S., and M.V.F.; resources, Y.S.; data curation, M.V.F.; writing-original draft preparation, R.M.M.; writing—review and editing, Y.S. and M.V.F.; visualization, M.V.F.; supervision, R.M.M.; project administration, R.M.M.; funding acquisition, Y.S. All authors have read and agreed to the published version of the manuscript.

Funding: This work was supported by the Union's co-financing European Union through the European Regional Development Fund. (Group for Research in Organizational Knowledge Innovation and Strategy, GROKIS, University of Castilla-La Mancha).

Conflicts of Interest: The authors declare no conflict of interest.

\section{References}

1. EU. The Entrepreneurship 2020 Action Plan. European Commission. Available online: https://ec.europa.eu/ growth/smes/promoting-entrepreneurship/action-plan_en (accessed on 10 February 2020).

2. Mair, J.; Martí, I. Social entrepreneurship research: A source of explanation, prediction, and delight. J. World Bus. 2006, 41, 36-44. [CrossRef]

3. Criado-Gomis, A.; Cervera-Taulet, A.; Iniesta-Bonillo, M.-A. Sustainable Entrepreneurial Orientation: A Business Strategic Approach for Sustainable Development. Sustainability 2017, 9, 1667. [CrossRef]

4. Schaltegger, S.; Wagner, M. Sustainable entrepreneurship and sustainability innovation: Categories and interactions. Bus. Strategy Environ. 2011, 20, 222-237. [CrossRef]

5. Eugine Tafadzwa, M.; Welcome, M.; Thobekani, L. Entrepreneurial Barriers that are Confronted by Entrepreneurs Living with Physical Disabilities: A Thematic Analysis. J. Econ. Behav. Stud. 2017, 9, 27-45. [CrossRef]

6. Dijkhuizen, J.; Gorgievski, M.; van Veldhoven, M.; Schalk, R. Feeling successful as an entrepreneur: A job demands-Resources approach. Int. Entrep. Manag. J. 2016, 12, 555-573. [CrossRef]

7. Schaub, M.; Tokar, D.M. The role of personality and learning experiences in social cognitive career theory. J. Vocat. Behav. 2005, 66, 304-325. [CrossRef]

8. Brown, S.D.; Lent, R.W. Social Cognitive Career Theory at 25: Progress in Studying the Domain Satisfaction and Career Self-Management Models. J. Career Assess. 2019, 27, 563-578. [CrossRef]

9. Vanevenhoven, J. Advances and Challenges in Entrepreneurship Education. J. Small Bus. Manag. 2013, 51, 466-470. [CrossRef]

10. Bae, T.J.; Qian, S.; Miao, C.; Fiet, J.O. The Relationship Between Entrepreneurship Education and Entrepreneurial Intentions: A Meta-Analytic Review. Entrep. Theory Pract. 2014, 38, 217-254. [CrossRef]

11. Sitkin, S.B.; Pablo, A.L. Reconceptualizing the Determinants Of Risk Behavior. Acad. Manag. Rev. 1992, 17, 9-38. [CrossRef]

12. Liguori, E.; Winkler, C.; Vanevenhoven, J.; Winkel, D.; James, M. Entrepreneurship as a career choice: Intentions, attitudes, and outcome expectations. J. Small Bus. Entrep. 2019, 1-21. [CrossRef]

13. Hansemark, O.C. Need for achievement, locus of control and the prediction of business start-ups: A longitudinal study. J. Econ. Psychol. 2003, 24, 301-319. [CrossRef]

14. Miettinen, M.R.; Littunen, H. Factors Contributing to the Success of Start-Up Firms Using Two-Point or Multiple-Point Scale Models. Entrep. Res. J. 2013, 3, 449-481. [CrossRef] 
15. Fietze, S.; Boyd, B. Entrepreneurial intention of Danish students: A correspondence analysis. Int. J. Entrep. Behav. Res. 2017, 23, 656-672. [CrossRef]

16. Laspita, S.; Breugst, N.; Heblich, S.; Patzelt, H. Intergenerational transmission of entrepreneurial intentions. J. Bus. Ventur. 2012, 27, 414-435. [CrossRef]

17. Aldieri, L.; Kotsemir, M.; Vinci, C.P. The role of environmental innovation through the technological proximity in the implementation of the sustainable development. Bus. Strategy Environ. 2019, 29, 493-502. [CrossRef]

18. Khan, J.; Hildingsson, R.; Garting, L. Sustainable Welfare in Swedish Cities: Challenges of Eco-Social Integration in Urban Sustainability Governance. Sustainability 2020, 12, 383. [CrossRef]

19. Aldieri, L.; Grafström, J.; Sundström, K.; Vinci, C.P. Wind Power and Job Creation. Sustainability 2020, $12,45$. [CrossRef]

20. Lee, S. Role of social and solidarity economy in localizing the sustainable development goals. Int. J. Sustain. Dev. World Ecol. 2020, 27, 65-71. [CrossRef]

21. Kulkarni, M. Organizational career development initiatives for employees with a disability. Int. J. Hum. Resour. Manag. 2016, 27, 1662-1679. [CrossRef]

22. Cohen, B.; Winn, M.I. Market imperfections, opportunity and sustainable entrepreneurship. J. Bus. Ventur. 2007, 22, 29-49. [CrossRef]

23. Shepherd, D.A.; Patzelt, H. The New Field of Sustainable Entrepreneurship: Studying Entrepreneurial Action Linking "What is to be Sustained" with "What is to be Developed". Entrep. Theory Pract. 2011, 35, 137-163. [CrossRef]

24. Cohen, B. Sustainable valley entrepreneurial ecosystems. Bus. Strategy Environ. 2006, 15, 1-14. [CrossRef]

25. Schaltegger, S. A Framework for Ecopreneurship: Leading Bioneers and Environmental Managers to Ecopreneurship. Greener Manag. Int. 2002, 38, 45-58. [CrossRef]

26. Zhiwei, Y.; Xuanwei, C.; Hongyi, D.; Yun, H. Is entrepreneurial orientation a good predictor of sustainable performance? J. Asia Entrep. Sustain. 2018, 14, 124-165.

27. Parker Harris, S.; Renko, M.; Caldwell, K. Social entrepreneurship as an employment pathway for people with disabilities: Exploring political-economic and socio-cultural factors. Disabil. Soc. 2014, 29, 1275-1290. [CrossRef]

28. Maritz, A.; Laferriere, R. Entrepreneurship and self-employment for people with disabilities. Aust. J. Career Dev. 2016, 25, 45-54. [CrossRef]

29. WHO. Disability. Available online: https://www.who.int/disabilities/en/ (accessed on 10 December 2019).

30. Dhar, S.; Farzana, T. Entrepreneurs with disabilities in Bangladesh: An exploratory study on their entrepreneurial motivation and challenges. Eur. J. Bus. Manag. 2017, 9, 103-114.

31. Zahari, A.R.; Tamyez, P.F.M.; Azizan, N.A.; Hashim, F. Student Spin-Off Intentions In Malaysian Higher Educational Institutions: Founders' Characteristics And University Roles. J. Entrep. Educ. 2018, 21, 1-15.

32. Nowiński, W.; Haddoud, M.Y.; Lančarič, D.; Egerová, D.; Czeglédi, C. The impact of entrepreneurship education, entrepreneurial self-efficacy and gender on entrepreneurial intentions of university students in the Visegrad countries. Stud. High. Educ. 2019, 44, 361-379. [CrossRef]

33. Achterberg, T.J.; Wind, H.; de Boer, A.G.E.M.; Frings-Dresen, M.H.W. Factors that Promote or Hinder Young Disabled People in Work Participation: A Systematic Review. J. Occup. Rehabil. 2009, 19, 129-141. [CrossRef]

34. Jones, M.K.; Latreille, P.L. Disability and self-employment: Evidence for the UK. Appl. Econ. 2011, 43, 4161-4178. [CrossRef]

35. Balcazar, F.E.; Kuchak, J.; Dimpfl, S.; Sariepella, V.; Alvarado, F. An empowerment model of entrepreneurship for people with disabilities in the United States. Psychosoc. Interv. 2014, 23, 145-150. [CrossRef]

36. Roni, N.N.; Baines, S. Why entrepreneurship process as a battle for business resources recognition for disadvantaged people? J. Bus. Stud. 2012, 33, 55-90.

37. Uddin, M.; Jamil, S.A. Entrepreneurial Barriers Faced by Disabled in India. Asian Soc. Sci. 2015, 11, 72-78.

38. Maria Munoz, R.; Salinero, Y.; Pena, I.; Sanchez de Pablo, J.D. Entrepreneurship Education and Disability: An Experience at a Spanish University. Adm. Sci. 2019, 9, 34. [CrossRef]

39. van der Zwan, P.; Thurik, R.; Grilo, I. The entrepreneurial ladder and its determinants. Appl. Econ. 2010, 42, 2183-2191. [CrossRef]

40. von Graevenitz, G.; Harhoff, D.; Weber, R. The effects of entrepreneurship education. J. Econ. Behav. Organ. 2010, 76, 90-112. [CrossRef] 
41. Hernan-Gómez, J.; Martín, N.; Rodríguez, A.I. Education and training as non-psychological charcteristics that influence university students'entrepreneurial behaviour. J. Entrep. Educ. 2006, 9, 99-112.

42. Zhao, H.; Seibert, S.E.; Hills, G.E. The mediating role of self-efficacy in the development of entrepreneurial intentions. J. Appl. Psychol. 2005, 90, 1265-1272. [CrossRef]

43. Uddin, M.R.; Bose, T.K. Determinants of entrepreneurial intention of business students in Bangladesh. Int. J. Bus. Manag. 2012, 22, 225-248. [CrossRef]

44. Ferreira, J.J.; Raposo, M.L.; Gouveia Rodrigues, R.; Dinis, A.; do Paco, A. A model of entrepreneurial intention An application of the psychological and behavioral approaches. J. Small Bus. Enterp. Dev. 2012, 19, 424-440. [CrossRef]

45. Calderón-Milán, M.-J.; Calderón-Milán, B.; Barba-Sánchez, V. Labour Inclusion of People with Disabilities: What Role Do the Social and Solidarity Economy Entities Play? Sustainability 2020, 12, 1079. [CrossRef]

46. Aldieri, L.; Kotsemir, M.; Vinci, C.P. The impact of research collaboration on academic performance: An empirical analysis for some European countries. Socio-Econ. Plan. Sci. 2018, 62, 13-30. [CrossRef]

(C) 2020 by the authors. Licensee MDPI, Basel, Switzerland. This article is an open access article distributed under the terms and conditions of the Creative Commons Attribution (CC BY) license (http://creativecommons.org/licenses/by/4.0/). 